\title{
Adopted to Deal with Bastee Settlements of Dhaka City in Bangladesh
}

\author{
Mohammad Abdul Mohit \\ Kulliyyah (Faculty) of Architecture and Environmental Design, \\ International Islamic University Malaysia \\ mohd.mohit@gmail.com
}

\begin{abstract}
Dhakais the capital city ofBangladesh and ithas a population of 12 million. During the last three decades, while the city population grew over $7 \%$, bastee (slum and squatter) population of the city grew from 1.0 million in 1990 to 3.4 million in 2005. Several policy approaches were adopted to deal with bastee settlements of Dhaka since 1975. These policies approaches were notvery effective, because the scale of the problem is verylarge, which provides future challenges to deal with the bastee situation.

Keywords: Bastee, City Population, Dhaka, Migration, Policy Approaches.

eISSN 2514-751X @ 2018. The Authors. Published for AMER ABRA CE-Bs by e-International Publishing House, Ltd., UK. This is an open access article under the CC BY-NC-ND license (http://creativecommons.org/licenses/bync-nd/4.0/). Peer-review under responsibility of AMER (Association of Malaysian Environment-Behaviour Researchers), ABRA (Association of Behavioural Researchers on Asians) and cE-Bs (Centre for EnvironmentBehaviour Studies), Faculty of Architecture, Planning \& Surveying, Universiti Teknologi MARA, Malaysia.

DOI: https://doi.org/10.21834/aje-bs.v3i6.231
\end{abstract}




\subsection{Introduction}

Dhaka is the capital and primate city of Bangladesh with an estimated population of 12 million (2007). The city receives an estimated 300,000 to 400,000 rural poor migrants almost every year (Bangladesh Bureau of Statistics (BBS), 2001). In 1951, the city had a population of 335,928 and it grew to 12.0 million in 2007 with a growth rate of over $7 \%$. Commensurate with the increase of city population, bastee settlements have also grown very fast. Bastee settlements were formed in Dhaka during 1971-1986, at a rate of 20 settlements per year and then at a rate of 100 settlements per year (Prashika, 1996). In 1990, there were 1 million bastee dwellers in 2,156 clusters within the Dhaka metropolitan area and the number increased over the next 6 years to 1.5 million in over 2,800 clusters (Prashika, 1996). Between 1996 and 2005, the total slum population of Dhaka more than doubled from 1.5 to 3.4 million, while the number of slum communities increased by roughly $70 \%$, i.e., from 3,007 to 4,966 (CUS, 2006). Therefore, a regular influx of rural migrants into the city contributes to the growth and densification of slums that accentuates the shelter crisis leading to the deterioration of living environment of the city. Several policy approaches were adopted by the national government and local authorities since 1975 to address the slum/squatter situations of the city. However, other than fragmented studies, no comprehensive study has been carried out to evaluate these policies. Therefore, the present paper attempts to provide a critical assessment of the policy approaches undertaken to deal with the bastee settlements of Dhaka City and through it derive appropriate policy regime for their development.

\section{Objectives of the Study}

The main aim of the paper is to review the policies and approaches adopted to deal with bastee settelements of Dhaka City through focussing on the following objectives:

1) To present an overview of bastee settlements of Dhaka City;

2) To examine the policies and approaches adopted to deal with bastee settlements in the city;

3) To provide examples from innovative initiatives involving pro- poor strategies and community initiatives in project planning and management, and

4) To highlight critical issues and emerging future challenges and opportunities.

\subsection{Literature Review}

Globally, the intensity of slum problem has been highlighted by UN- HABITAT (2003) which reports that $1 / 3^{\text {rd }}$ of the world population is living in slums and if adequate measures are not immediately adopted the figure will reach $50 \%$ by 2030 . The same report provides that the number of people living in urban slums in Asia and Pacific is as high as 498 million, or $50 \%$ of the total urban population. CUS (2006) conducted a census and mapping of slums in six cities of Bangladesh in 2005 and prepared a report that generated a wealth of information about the location and basic characteristics such as population, households, basic demographic, socio- economic and environmental descriptions of the urban slums.

Bastee settlements are usually regarded as spatial manifestations of urban poverty where 
a significant portion of Dhaka city's dwellers live in informal settlements and they live below the poverty lines as the rapid growth of the city is not commensurate with its overall development (Hossain, 2008). World Bank (2007) presents a comprehensive picture of poverty in Dhaka with the goal of providing the basis for an urban poverty reduction strategy for government, local authorities, donors and NGOs (Non- Governmental Organizations). Abed (2007), while highlighted on the problems faced by the poor to get access to justice in both formal and informal legal system, commented that "access to justice is very important in order to find a way out of poverty" (p.3). Rashid (2007) analysed vulnerability of the urban poor to health problems, due to poverty, under-nourishment, and little access to health care, and found that communicable diseases are a major problem in slum population of Dhaka City. Begum and Moinuddin (2010) studied the relationship between housing and social exclusion in the slums of Dhaka City through six key elements and found each of these elements related to the process and outcomes involved in social exclusion is further related to the spatial marginality of bastee dwellers. Rashid (2009) reviewed policies, programmes and actions designed to impact the level of exclusion of people living in slum settlements of Bangladesh, with a focus on the health and rights of people living in these areas.

Eviction of bastees and violation of human rights in Bangladesh and Dhaka City have been the subject matter of many studies. COHRE (Centre on Housing Rights and Evictions) and ACHR (Asian Coalition of Human Rights) (2000) investigated forced evictions in Dhaka City during May-August 1999 and reports that 19,432 families or 100,000 people were made homeless. Similarly, Rahman (2001) reported about the chronological eviction of bastees from 1971 upto 1995, which often violated the rules of eviction and the violation of human rights. World Bank (2007) also reports about eviction of bastees from 1975 to 2004, despite that the country has adopted a National Housing Policy in 1993. Wakely (2007) reports that from January 2004 to June 2005, 27,055 people were evicted. Paul (2006) studied a bastee demolition programme in 1999, which was abandoned due to severe resistance; nevertheless, the threat of eviction did not completely disappear from the minds of bastee dwellers.

Earlier studies on bastees in Dhaka city were mostly descriptive and highlighted on the living conditions of the dwellers. A number of CUS studies, although comprehensive, are mainly descriptive and generally the characteristics of the settlements are described as very negative regarding the possibilities of a consolidation process emerging (Wendt, 1997). Qadir (1975) studied three squatter settlements in Lalmatia, Babupura and Naya Paltan of Dhaka City and provides detailed breakdown of the poorly paid jobs of the squatter family members and their poor living condition.

Choguill (1987) examined the planning and implementation of a small squatter resettlement at Bashantek in Mirpur, Dhaka, which revealed a wide range of implementation problems that frequently arises when new communities are designed and built in a resourcescarce situation. Wendt (1997) studied four bastees - Mohammadpur, Khilgaon, Embankment and Mirpur of Dhaka City, to analyse the possibilities/ constraints on the emergence of a consolidation process in Dhaka's bastee settlements and she observed that based on the elements determining the mobilisation potentials of bastee dwellers, it is not possible to trace any potentials for the emergence of an autonomous mobilisation process in Dhaka's slum and squatter settlements. Kamaruzzaman and Ogura (2006) applied the concepts of 
affordability, cost recovery and replicability to examine the aptness of the Bhashantek Rehabilitation Project (BRP). Haque (2007) studied Dattapara resettlement project which was expected to rehabilitate 5000 families, but due to coordination problem among different service providers, the project is not yet complete.

Some studies have investigated the involvement of NGOs in bastee improvement programmes by highlighting their problems and limitations and also areas where their involvement may be encouraged. Rahman (2005) investigated the reasons for the lack of NGO involvement in urban housing sector and recommended on the enhancement of affordability through savings and micro-credit. Habib (2009) reports that NGOs are reluctant to work for better housing for the slum dwellers because of tight government regulations and controls on urban land and the fear of governmentevictions. Nevertheless, some NGOs such as NUK (Nari Uddog Kendra) and BRAC (Bangladesh Rural Advancement Committee) have come up to provide shelter solutions to female garment workers of Dhaka City.

Despites the above issues, some studies report about the innovative initiatives or approaches developed by the NGOs to tackle service deficiencies and improve living environment of the bastee dwellers of Dhaka City. Such initiatives include-intermediation by an NGO in gaining access to water for the low-income communities of Dhaka City (Matin, 1999); an innovative approach developed an NGO to render water and latrine services to a rehabilitated slum of Dhaka City (Ahmad, 2006); development of a barrel type of composting for the slum dwellers (Waste Concern, 2005) and community clustered latrines managed by the CBOs (Community Based Organizations) built by an NGO (Tripathy, 2008).

It appears from the foregoing review that there is a large amount of literature which has investigated different aspects of bastee settlement problems in Dhaka City in a fragmented way. These studies require to be integrated to put forward the necessity of providing a coherent analysis for developing a policy regime to deal with slum situation of Dhaka city on a national and city-wide scale

\subsection{Methodology}

The paper is based on secondary literature on slums and squatters of Dhaka City. Factfinding studies on slum living conditions and issues are based both on general and individual case studies and reports. The information/data base of the paper have used the following types of materials: (a) International mission/ visit reports; (b) Government reports; (c) Research reports: (d) Journal articles; (e) Theses/ dissertations; and (f) News-paper articles/reports.

\section{Dhaka City - Characteristics and Living Environment of Bastee Settlements}

Dhaka, the capital of Bangladesh, is the largest city and it contains $34 \%$ of the national urban population of the country. Although bastee settlements existed in Dhaka for a long time but their growth accelerated after the liberation in 1971, due mainly to a high rate of annual rural migration. The bastee population of Dhaka is 3.4 million and the number of slum clusters is 4,966 (2005). Spatially, the distribution of slums remains similar during the last three decades, with more conspicuous growth in peripheral and suburban areas, due to land price differences 
between the core and peripheral areas. Private slums are on the increase compared to public slums because the government has become more vigilantinguarding its land against squatters. Supply of semi-permanent (brick wall-tin roof) houses in slums has increased along with an increase in rent. Among the slum dwellers, 52.3\% live in semi-permanent houses while 39.7\% live in kutcha jhupries (flimsy impoverished dwellings) (CUS, 2006, p.21).

The slums of Dhaka City occupies only $5.1 \%$ of the city's total land (1,542 hectares) accommodating $37.4 \%$ of the total city population. While the overall gross population density for Dhaka is less than 121 persons/ acre, the population density in slums is 891 persons/acre, which is nearly 7 times higher than the city average. Using a household income of Tk 5,000 (US\$715.00) per month as a reference of poverty line, the study (CUS, 2006) reported that the slums are generally the places of concentrated poverty, with $85.4 \%$ residents living below the poverty line in Dhaka city. The largest single slum in Dhaka was found at Korail in Mohakhali, with more than 100,100 people. While $10 \%$ of slums had sufficient drainage to avoid water-logging during heavy rainfall, over half were typically fully or partially flooded during monsoon. More than $50 \%$ of the slums had no fixed place for either garbage collection or disposal. However, $96 \%$ of bastee dwellers of Dhaka city have access to electricity. A similar proportion had access to safe water. The Dhaka slum residents mainly rely on municipal taps for drinking water. Only around $5 \%$ of slum households did not share their drinking water source, while $40 \%$ shared it with more than 11 families. Almost $58 \%$ of the slums of Dhaka did have access to cooking gas. Most (65\%) of Dhaka slums had no access to safe latrines. In nearly all slums, latrines were shared and in $50 \%$ slums, it was shared by at least 6 families.

Roughly $6 \%$ of slums had experienced fire at some point. Around $7 \%$ slums had either been evicted at least once from their present location or were facing the threat of eviction. $56 \%$ of residential structures in the slums were made of low quality materials.

\subsection{Results and Discussion}

The paper examines the formation and consolidation of bastee settlements of Dhaka City from different perspectives and the sections below provides the results of the study.

\section{Approaches to Deal with Bastee Settlements in Dhaka City}

Since 1975, a number of policy approaches were adopted to tackle the bastee settlements of Dhaka City and below are provided an assessment of those attempts and their effectiveness.

\section{Evictions}

Bastee settlements in Dhaka City usually occupy public or private land and they are often evicted from their settlements. COHRE and ACHR (2000) in their fact finding mission on forced eviction reports that "the homes of 44 settlements have been demolished in the past one year making 19,432 families or approximately 100,000 people homeless" (p.36). The report concludes that wide spread forced evictions did indeed take place, in violation of both international and national laws and therefore urged the government to abide by its legal obligations to cease such evictions. Similarly, Rahman (2002) observed that there has been chronological eviction of bastees from 1971 upto 1995, which often violated the rules that 
require a 30 days notice to legally evict unauthorised occupants [vide Government and local authority land and building (recovery \& possession) ordinance 1970], leading to the violation of human rights. From 1975 to 2004, there have been 135 instances of evictions in Dhaka City. While the number of slum dwellers evicted in each is not known, the list clearly shows that evictions have not slowed down since the adoption of the National Housing Policy in 1993 (World Bank, 2007). The large-scale eviction in Agargaon affected an estimated 40,000 slum dwellers. Wakely (2007) that from January 2004 to June 2005, 27,055 people were evicted in 17 incidents of which 13 by government and 4 by private groups; the reasons given were environmental clean-up, building shopping complexes, land grab and infrastructure development.

According to Wendt (1997) governments in developing countries usually justify evictions in one of the four ways - (a) to improve or beautify the city; (b) to clear dens (bastes) of criminals; (c) for fear that health problems will spread from slums; and (d) clear land for development or to build public offices. Eviction has three basic impacts on those affected: physical, economic and psychological (UN-HABITAT, 2003). While the eviction is a traumatic experience in itself, the most harmful impact of eviction may actually bethe fear ofbeing evicted. The fear makes people fatalistic; people lose confidence in themselves and it discourages them from improving their housing. Paul (2006) in his case study of a Bastee eviction in 1999 (later on abandoned) found that the overwhelming majority of respondents fear eviction and do not want to return to their villages. The study also found that past eviction and previous Bastee experience, length of stay in Dhaka and having close friends, relatives who live in Dhakaare important determinants of respondent fear of eviction.

\section{Resettlements through Sites-and-Services Schemes}

Resettlement bastee dwellers through the sites-and-services schemes were attempted in three areas in Dhaka following the eviction of 173,000 dwellers in 1975. The three resettlement schemes area - (a) Dattapara in Tongi, (b) Chanpara in Demra, and (c) Bhashantek in Mirpur.

The Dattapara resettlement project on a 101-acre land area intended to resettle 5000 squatter families. So far 30 acres of land have been developed with site and service with a plot size of $600 \mathrm{sq} \mathrm{ft}\left(30^{\prime} \times 20^{\prime}\right)$ each and 1016 squatter families are residing. The rest of the land has been occupied by unauthorised low-income poor families. At present, 7,787 low income families are residing there. The project is not yet complete and a few issues such as absence of land titles, understanding gap between service providers and dwellers and above all, coordination problem among different service providers, are held responsible for the noncompletion of the project(Haque, 2007, p.11).

The Chanpara resettlement project, located on the Lakya River about ten miles to the east of Dhaka City on a 103-acre land area intended to resettle 5000 squatter families. The land was originally acquired by the Dhaka Water and Sewerage Authority (DWASA), as a site for water treatment plant. The project was completed with NGO assistance and currently an NGO works for environmental improvement of the community (Ahmed, 2006).

The Bhashantek resettlement project was initiated in 1975 on 88 acres of land to create 4000 plots and resettle similar number of families, near Dhaka Military Cantonment in Mirpur. 
But in 1977, due to military strategic reasons, it was relocated to low-lying land $2 \mathrm{~km}$ to the north- west with the UNCDF fund. The project was revised three times because each time it was about to be implemented, some faults such as costly land development techniques, incorrect embankment design (and its eventual collapse), overlooking project management and operation of the pumps, lack of co-ordination and leadership among many participating agencies, etc., were identified (Choguill, 1987, 1994). In the end, the project was completed, but was highly subsidised, endangering replication of such a project in the future.

According to one expert (Choguill, 1987), the planning carried out for the above three projects was inadequate. No effort was made to involve the squattersthemselves in the solution and the entire problem of their economic livelihood seemed to either have been overlooked or underestimated (p.101).

Dhaka City Corporation had two relatively small sites-and-services schemesas wellasa slum upgrading programme which had benefitted about 5,000 households. Those programmes were clearlynotvery extensive when compared with the scale of the problem in Dhaka.

\section{Slum Upgrading Programme (SIP)}

Slum upgrading as a cost-effective approach has been widely used across developing countries. According Choguill (1994), a number of advantages of informal housing upgrading can be identified. First, it preserves existing economic systems and opportunities for urban poor. Second, it maintains the community structure and safeguards that already exist in the community group. In this way, the urban poor do not lose their jobs as they are engaged. Third, upgrading tends to be affordable than sites-and-services projects.

The Bangladesh government started implementing upgrading programmes in urban slums from mid-1980s with UNICEF. This programme is active in some 25 cities, including Dhaka. Originally, the programme had a strong physical component like improvement of drains and sanitation. It had no housing component. Later the World Bank (WB), the ADB (Asian Development Bank) and major NGOs like CARE supported some slum improvement. None in Dhaka, however, has any housing component. Dhaka City Corporation itself established its own Slum Improvement Department in the early 1990s, but fund allocations to this department has always been very small (World Band, 2007). DCC has, however, implemented three SIPs Shahid Nagar, Rosulpur, and Islambagh.

Siddique, et al., (2002) studied 18 SIP within Dhaka metropolitan area under implementation by the Local Government Engineering Department (LGED) and reports that upgrading of physical infrastructure under SIP included the development of footpaths and drains, the installation of tube-wells, latrines, street lighting, which led to improvement of slum environment and health conditions of poor and their quality of life. But maintenance of drains and refuse collection seems very poor in some slums. Social mobilisation, leadership training for people's organisations and possible linkages between women and existing legal aid-related institutions including tenure security need to be promoted in the SIPs. Once tenure becomes more secure, tenants are likely to pay more attention to improving their slums (p.101).

All SIPs together have made very little impact on improvement of slums in Dhaka, due to the massive scale of the problem (World Bank, 2007). In spite of the good intentions behind the programmes, evaluations have shown that, at best, the projects only provided a partial 
solution to housing problems, because only an insignificant percentage of the urban poor benefitted. Owing to the improvements, the price of land increased and pushed the poor to the fringe areas of the cities where employment opportunities are scarce. (Wendt, 1997).

One important aspect of SIP in urban areas of Bangladesh is the limited involvement of NGOs, both in number and activities (World Bank, 2007). A few NGOs operate in Dhaka City mostly in income generating projects and they are not interested in shelter projects for the urban poor. Habib (2009) found that NGOs are reluctant to work for better housing for the slum dwellers because of tight government regulations and controls on urban land and distribution systems, and for fear of government evictions. In the past, some NGOs even filed High Court $(\mathrm{HC})$ Cases against government on eviction issues. The HC directed the government not to evict slum dwellers without offering to re-house them, but these verdicts were not properly implemented. Because of these NGOs who might wish to provide credit and other support services, do not come forward (p.263). Rahman (2005) identified several similar reasons for the lack of NGO involvement in urban housing sector.

\section{Back to Home (Ghore Phera) Programme}

In 1999, Bangladesh Krishi (Agriculture) Bank at the initiative of the government started the Ghore Phera (back to home) programme, which encouraged people to return to their villages by offering them loans ranging from Taka 20,000 to Taka 150,000 and in some cases Taka $3,000,000$, to start income generating activities. The programme ostensibly aimed at alleviating urban poverty, reducing rural urban migration, and improving the city environment through encouraging the slum dwellers to leave their filthy and unhygienic bastees. It is reported that 1,746 families received loan and returned to their villages. One community leader commented that this programme coincided with forced bastee evictions of 1999 and the selection criteria was not transparent. They also reported that many people who availed the loans returned to the slums after some months. The community leaders also considered the programme as a wastage of resources. The assumption that people living in slum settlements for decades would return to their villages, leaving behind extensive social and economic networks and employment opportunities, is unfounded. (Rashid, 2009). On a similar context, Bhuyan, et.al., (2001) remarked that unless the benefits of migration can be generated in the rural setting even by a modest proportion, if not to the fullest extent, the idea of initiating and sustaining the process of reverse migration will not be translated into reality

\section{Bhashantek Rehabilitation Project - Public-Private Partnership (PPP)}

In 1998, the government allocated 47.9 acres of land in Bhashantek of Mirpur Section15. Dhaka, under the name Bhashantek Rehabilitation Project (BRP) with a view to constructing a modern satellite town for the bastee dwellers and the low income group people of Dhaka City. Accordingly, a public-private partnership (PPP) agreement was signed between the Ministry of Land and North South Property Development Ltd. (NSPDL), on September 29, 2003. According to the agreement, NSPDL will implement the total project with their fund. Under the project a total of 15,024 flats will be constructed, of which 9,024 for bastee dwellers (Type-A: one room, $215 \mathrm{sq} \mathrm{ft}$ ) and 6,000 for low-income families (Type-B: two room, $395 \mathrm{sq} \mathrm{ft}$ ).

Kamaruzzaman and Ogura (2006) examined the aptness of the BRP, based on the 
affordability, cost recovery and replicability concept and found that BRP is poorly fitted to target population and ithas a clear disparity with its aim which might not well curve the housing dearth of the real poor. A more sophisticated role of the state is necessary to provide the institutional support for well-functioning of property markets as well as to capture the opportunities of high property market value. Karmakar (2009) reports that hundreds of flats constructed for the bastee dwellers have allegedly been allocated to the financially solvent people. No bastee dwellers have been able to purchase these flats. According to contract document, the Dhaka district administration would hand over the document of purchasing flat on the recommendation of approval committee of Land Ministry. But the NSPDL has been selling flats violating rules mentioned in the contract paper. So major problems may arise in handing over the flats to the buyers.

\section{Contracting for Health Services in Slum Settlements under Public-Private Partnerships (PPP)}

The Urban Primary Healthcare Project (UPHCP) under PPP between local government and NGOs/private clinics was initially implemented in four cities - Dhaka, Khulna, Chittgong and Rajshahi, to reach out the poor and provide quality primary healthcare services to bastee dwellers. The first partnership agreements were signed in May 2000 and the second batch of eight partnership agreements was signed in mid-2001. Under this project, the UPHCP, established healthcare centres in low-income areas of the participating cities through which NGOs were subcontracted to provide primary healthcare services. There were 16 partnership agreements with 14 NGOs and two with the Chittagong City Corporation. In 2001, the coverage included 400,000 people in four city corporation areas. With assistance from the Asian Development Bank (ADB), the city corporation has built 124 primary healthcare facilities owned by the NGOs providing services.

Very few studies have been undertaken to evaluate UPHCP programme which is now in its $2^{\text {nd }}$ phase. Ahmad (2007) has identified several weaknesses of the programme-firstly, the accountability relationship is not transparent, the programme is costly due to high transaction, management and monitoring costs, existing institutional arrangement is difficult to expand without external assistance, and there is lack of a sense of ownership and trust in its continuity among the population. Most of the slum and street dwellers have limited access to health care because the centres open after they got out to work and close by the time they are back to their huts (The Daily Star On line, May 19, 2011). Even though the government is spending Taka 10.0 millions on an average every year under the UPHC Project, essential health care is a far cry for slum and pavement dwellers (The Daily Star Online, May 19, 2011).

It appears from the foregoing analysis that besides evictions, policy approaches adopted by government, local authority and NGOs are beset with many shortcomings which need ratifications. Moreover, theattempts have been meagre compared to the scale of the problem. A comprehensive city-wide approach involving the various stakeholders is essential.

\section{Innovative Initiatives and Approaches}

Despite the fact that the above policy approaches have limited successes, some NGO 
initiatives towards slum upgrading may claim to be innovative even within the difficult environment in which they are operating in the bastee settlements of Dhaka City. Such initiatives include - (a) an enabling strategy initiated by an NGO - DSK (Dustha Sastha Kendra) (a partner of Water Aid Bangladesh), in gaining access to water for the low-income communities of Dhaka City (Matin, 1999; Jinnah, 2007); (b) an innovative approach developed to render water and latrine services to the rehabilitated Chanpara slum of Dhaka City by using an approach of wealth ranking designed to categorise household's ability to pay for hand tube-wells and sanitary latrines (Ahmad, 2006); (c) development of a barrel type of composting for the bastee settlements which can help in achieving a behavioural change by minimizing littering of waste in slum, improve the environment and create a source of income for the poor slum dwellers (Waste Concern, 2005) and (d) the success of community clustered latrines managed by the CBOs (Community Based Organizations) built by ASD (Assistance for Slum Development), a partner organization of Water Aid Bangladesh (Tripathy, 2008).

\section{Critical Issues and Emerging Challenges}

Based on literature review, three critical issues - (a) the availability of low-cost urban land for housing the poor; (b) the provision of access to affordable housing to help the poor to improve their housing; and (c) the organisation and participation of the community in planning and implementing low-income housing, need to be tackled in confronting the urban shelter crisis in Dhaka City and in controlling the future growth of bastees. According to World Bank (2007), the main challenges facing Dhaka in the next years with regard to land and housing for the poor are, viz., coping with sustained arrival of poor migrants, environmental risks, evictions, delivery of basic services, and security of tenure sustainable housing. In order to meet the emerging challenges, upgrading of existing bastee housing stock and services, improvement of security of tenure, are at present, essential at a meaningful scale. Future housing needs must be met through a judicious, flexible and innovative mix of policies to release suitable land, provide incremental services and infrastructure development and provide technical and financial support to the poor (Wakley, 2007).

\subsection{Conclusion}

The paper has examined a variety of policies and approaches adopted to combat bastee settlements of Dhaka City since 1975. The policy approaches have achieved limited success because the scale of the problem is very large. Therefore, a number of basic policy changes are necessary to towards creating an effective and enabling environment for improving the shelter conditions for the urban poor of Dhaka City.

These are, viz.,

(a) Implementing the National Housing Policy; (b) Strengthening public institutions to implement NHP; (c) Developing mechanisms for better land use and better coordination of services in the city; (d) Promoting coordination between DCC (Dhaka City Corporation), RAJUK (Capital Development Authority), line ministries and utility agencies in urban projects in Dhaka; (e) Strengthening the performance of RAJUK; (f) Initiating pilot projects in poor areas in partnership with NGOs; (g) Improving legal and regulatory framework; and (h) Promoting NGO 
initiated innovative approaches (World Bank, 2007). In addition, there is a need to promote secondary cities around Dhaka to diffuse the growth of Dhaka city so that a part of existing bastee population and future rural migrants will be attracted to these cities.

\section{References}

Abed, F.H. (2007). The Inclusion of Poor in Formal and Informal Legal System. Dhaka: BRAC.

Ahmad, A. (2007). Provision of Primary Healthcare Services in Urban Areas of Bangladesh - the Case of Urban Primary Care Project. Working Paper-07, Sweden: Lund University Economics Department.

Ahmed, R. (2006). Sustainable Development of Water Resources, Water Supply and Environmental Sanitation - A Case Study on Reaching the Poorest and Vulnerable. $32^{\text {nd }}$ WEDC International Conference, Colombo, Sri Lnaka.

Bangladesh Bureau of Statistics (BBS) (2001). Population Census 2001- Preliminary Report. Dhaka: BBS.

Begum, H. and Moinuddin, G. (2010). Spatial dimension of social exclusion, an imperial investigation into the relationship of housing and social exclusion in the slums of Dhaka City. Management Research and Practice, 2(3): 314-328.

Bhuyan, A.R., Khan, H. and Ahmed, S.U. (2001). Rural-Urban Migration and Poverty: The Case of Reverse Migration in Bangladesh. Dhaka: CIRDAP.

Choguill,C.L.(1994).Implementingurbandevelopmentprojects-asearch for criteria for success. Third World Planning Review, 16(1): 25-40.

Choguill, C. L. (1987). New Communities for Urban Squatters: Lessons from the plan that failed in Dhaka, Bangladesh. New York: Plenum Press.

COHRE and ACHR (2001). We Didn't Stand a Chance - Forced Eviction in Bangladesh. Mission Report. Geneva and Bangkok: COHRE and ACHR.

CUS (Centre for Urban Studies) (2006). Slums of Urban Bangladesh. Dhaka: CUS, Bangladesh.

CUS (1996). Survey of Slums and Squatter Settlements in Dhaka City. Dhaka: CUS.

Habib, E (2009). The role of government and NGOs in slum development: the case of Dhaka City. Development in Practice, 19(2): 259-265.

Haque, M. S. (2007). Shelter Design and Development - Bangladesh Perspective: In search of Sustainable Shelter for the Urban Poor. Dhaka: MH\&PW. (surfed from internet).

Hossain, S. (2008). Rapid Urban Growth and Poverty in Dhaka City, Bangladesh e-Journal of Sociology, 5(1), 5780 .

Karmakar, P. (2009). Slum dwellers deprived of flats at Bhashantek, New Nation Online, 15 May, 2011.

Kamaruzzaman,M., and Ogu,N.(2006).PolicyParadoxinHousing Supply for the Urban Poor: A Case of Dhaka City, Bangladesh. Journal of Architecture and Planning (AIJ), 74(643): 1969-1975.

Matin,N.(1999). Social-Intermediation:TowardsGainingAccesstoWater for Squatter Communities in Dhaka. Dhaka: 
UNDP/WB/SADC/ Water Aid/ DSK.

Paul, B.K. (2006). Fear of Eviction: Case of Slums and Squatter Dwellers in Dhaka, Bangladesh. Urban Geography, 27(6): 567-574.

Prashika (1996). Report of the Urban Poverty Reduction Project. Dhaka: ADB-GOB-LGED.

Qadir,S.R.(1975). Bastees ofDacca:A Study of Squatter Settlement. Dhaka: Local Government Institute.

Rashid, S.F. (2009). Strategies to reduce exclusion among population living in urban slum settlements in Bangladesh, Journal of Health, Population and Nutrition, 27(4): 574-586.

Rashid, S.F. (2007). Urban poverty and social exclusion: challenges ahead. Paper presented at Global Forum for Health Research, Forum II, Beijing, China, 9 Oct - 2 Nov.

Rahman, M.M. (2005). Role of the NGOs in Urban Housing for the Poor in Dhaka, Bangladesh. GBER 5(1): 16-29.

Rahman,M.M.(2001). Basteeevictionandhousingrights:AcaseofDhaka, Bangladesh. Habitat International, 25(2): 4967.

Siddique, Q.I., Alam, A.B.M., Rahman, M., Rahman, A. and Jahan, Hasin (2002). Slum ImprovementProject in Dhaka Metropolitan City. ASIAN PERSPECTIVE, HABITAT EXCHANGE, Canada.

Tannerfeldt, G. and Per Ljung (2006). More Urban Less Poor. Dhaka: SIDA.

The Daily Star Online, May 19, 2011.

Tripathi, S. (2008). WATSAN Activities in South Asia - An Experience from Dhaka, Bangladesh. Nepal: DEPHE, Nepal Engineering College.

UN-HABITAT (2003). Global Report on Human Settlements 2003. London: Earthscan.

Wakely, P. (2007). Quick Guide on Approaches to Low-income housing. Nairobi: UN-HABITAT.

Waste Concern (2005). Waste is Resource - Community Based SWM in Dhaka. Dhaka: SEMP/UNDP.

Wendt, S. (1997). Slum and Squatter Settlements in Dhaka: A study of consolidation processes in Dhaka's low income settlement areas. Ph.D. Dissertation, Roskilde University, Denmark.

World Bank (2007). Dhaka: Improving Living Conditions for the Urban Poor. Bangladesh Development Series Paper No. 17. Dhaka: The World Bank Office. 